Fisheries Research

June 2016, Volume 178, Pages 26-38

http://dx.doi.org/10.1016/i.fishres.2015.11.018

http://archimer.ifremer.fr/doc/00301/41214/

(c) 2015 Elsevier B.V. All rights reserved.

\title{
A partnership between science and industry for a monitoring of anchovy \& sardine in the Bay of Biscay: When fishermen are actors of science
}

\author{
Massé Jacques ${ }^{1}$, Sanchez Florence ${ }^{2,}{ }^{*}$, Delaunay Damien ${ }^{3}$, Robert J.M. ${ }^{4}$, Petitgas Pierre ${ }^{1}$ \\ ${ }^{1}$ Ifremer, Laboratoire Écologie et Modèles pour l'Halieutique RBE/EMH, Rue de l'île d'Yeu, BP 21105, \\ 44311 Nantes Cedex 3, France \\ ${ }^{2}$ Ifremer, Laboratoire Ressources Halieutiques Aquitaine RBE/HGS/LRHA, UFR Côte Basque, Anglet, \\ France \\ ${ }^{3}$ Comité Régional des Pêches et des Élevages Marins d'Aquitaine, 12 Quai Pascal Elissalt, 64500 \\ Ciboure, France \\ ${ }^{4}$ Conseil Consultatif Sud (C.C. Sud), 6 rue Alphonse Rio, 56100 Lorient, France \\ * Corresponding author : Florence Sanchez, Tel.: +33229008598 ; \\ email address : florence.sanchez@ifremer.fr
}

\begin{abstract}
:
Anchovy and sardine are small pelagic species occupying similar geographic areas in the Bay of Biscay (North-East Atlantic). Their biomass is strongly dependent on recruitment, making the annual assessment of TAC (Total Allowable Catch) a risky strategy due to uncertainty in predicting the magnitude of recruitment. Monitoring these resources more often and throughout their life cycle could allow management strategies to be adjusted based on observations which indicate the level of recruitment. In order to achieve a more frequent monitoring, an innovative data collection strategy involving a partnership between fishermen and scientists, was developed in 2009 and 2010 called "pilot sentinel surveys". This paper details the partnership, the information such a partnership can provide and how it can be useful for adaptively managing such resources. The method was based on short surveys undertaken by commercial vessels several times per year, in two spatially limited "key areas" known to be potential recruitment habitats. Acoustic surveys and fishing operations enabling biological sampling, were combined in each key area. Only one scientist was on board and an ad hoc sampling strategy was adopted during each survey by the Captain-Scientist team depending on the local conditions. This partnership allowed scientists to benefit from fishermen's experience and therefore adopt a sampling strategy which was optimized in time and space. The sentinel survey data were complemented with data collected during annual spring acoustic surveys carried out by the research vessel (RV) Thalassa. The RV was accompanied by commercial vessels allowing additional fishing operations and acoustic echo interpretation to be performed. This experiment showed that the sentinel observations in limited areas cannot provide reliable abundance indices, but are adequate to provide significant biological information on the seasonal progress of the life cycle of each species, such as growth, timing of incoming recruitment and migration pattern. In addition, these "pilot sentinel surveys" significantly improved the mutual understanding between fishermen and scientists.
\end{abstract}




\section{Highlights}

- Fishermen were key players in a collaborative research on pelagic species monitoring. Sporadic surveys in key areas are relevant to monitor anchovy recruitment arrivals. Fishermen can collect acoustic and biological data to monitor small pelagic stocks.

Keywords : Sporadic acoustic surveys, Bay of Biscay, Small pelagic monitoring, Recruitment indicators, Fishermen's surveys 


\section{Introduction}

Small pelagic species such as anchovy (Engraulis encrasicolus) and sardine (Sardina pilchardus) constitute important fish resources in the Bay of Biscay (Fig. 1), mainly exploited by Spanish purse seiners and French pelagic pair trawlers. In this area, anchovy has been managed by TAC (Total Allowable Catch) since 1980 whereas there is no present or planned EU management for sardine. Anchovy biomass dynamics are strongly dependent on recruitment (which is defined as 1 year old for these species), which represents generally $70 \%$ of the stock (up to $90 \%$ in some years) for anchovy and $60 \%$ for sardine (Silva et al., 2009).

\section{Insert Fig. 1}

In 2002, anchovy recruitment declined leading to a collapse of the stock biomass in 2003 and a closure of the fishery between 2005 and 2010 (ICES, 2013). Recruitment magnitude depends on summer larval drift and survival, and also winter juvenile survival. Until now, attempts to predict recruitment magnitude (age-1 in subsequent year) based on environmental conditions (Borja et al., 1996, 2008; Allain et al., 2001, 2007; Fernandes et al., 2010; Huret et al., 2010; Petitgas et al., 2011) have not been considered reliable enough by ICES to be used in management (ICES, 2007). The standing stock in the current year is assessed by ICES based on spring surveys at spawning time and on annual catches. ICES advises in the current year $(t)$ on a TAC for year $(t+1)$ based on the assessment of the current standing stock and an estimation of possible recruitment magnitudes for year ( $t+1)$. Juvenile acoustic surveys (Boyra et al., 2013) in autumn have been used to adjust the TAC $(\mathrm{t}+1)$ at the end of year $(\mathrm{t})$, but inaccuracy in estimating total juvenile abundance, as well as unpredictable winter juvenile survival can be problematic for recruitment prediction (ICES, 2006). Here, we consider another approach to "in season" monitoring of the resource's biology throughout its life cycle in specific habitats. The approach is based on the idea that the state of the resource and the 
recruitment magnitude could be assessed by capturing the seasonal evolution of certain key biological indicators. For example, anchovy growth rate is a key parameter in determining the dynamics of the population as it regulates reproductive potential (Pecquerie et al., 2009). Another important parameter is the occupation of offshore habitats (Petitgas et al., 2012) and also potentially the migration pattern to summer/autumn feeding habitats located in northern Biscay (ICES, 2010). This approach is also applied to sardine, which occupies somewhat similar geographic areas as anchovy in Biscay (ICES, 2010). Sardine, however, has a larger spatial distribution than anchovy and a different management context.

The aim of this paper is to describe an innovative data collection strategy, which was carried out in partnership with fishermen. The strategy was designed to cover key areas and seasons using small targeted scientific investigations. These investigations were undertaken considering fishermen's local knowledge, taking advantage of their experience instead of relying on one single comprehensive scientific survey in spring. This pilot study called "sentinel surveys" was conducted between 2009 and 2010 as a proof of concept and consisted of acoustic surveys of two sites and collection of biological samples using commercial fishing vessels. This paper describes the approach and the data collected with some examples of results and proposals for indices which could be used to monitor recruitment and describe the condition of adults throughout the year. Such indices could be used to develop sustainable management options including harvest rules (e.g., spatial and/or temporal closures in sensitive areas).

\section{Material and methods}

Independent of annual scientific assessment surveys which are used to assess biomass, 5 short "sentinel surveys" were organized from April 2009 to September 2010 on board commercial vessels. Sentinel surveys were carried out in order to collect relevant, targeted data throughout 
the year about sardine and anchovy in the Bay of Biscay, thus avoiding full scientific surveys on board research vessels which are expensive and not easy to mobilize. The idea was to involve fishermen and to take advantage of their knowledge and know-how. Preliminary meetings revealed that some of them were already willing to volunteer for scientific investigations which could provide better knowledge about the exploitation of fishery resources and possible elements for management considerations. It was nevertheless necessary to collect data outside the period when they were involved in sardine or anchovy fishery. However, outside this period (mainly the spawning season) they were usually committed to other fisheries (involving different species, areas, and/or equipment). It was therefore necessary to provide financial compensation to retain volunteers. Onboard such ships the fishing gear was adequate for the research purposes, but the onboard echo-sounder was generally uncalibrated and had no data storage capacity. Therefore a scientific echosounder and operator were added. Finally, a sampling strategy was developed so that data could be collected, while giving the captain sufficient freedom to benefit from his knowledge and intuition.

\section{Insert Table 1}

\subsection{Sampling strategy and data acquisition}

The sentinel surveys were carried out for a total of 24 days (Table 1). Three different pair trawlers participated in the survey operations (Table 1) over the18 month duration of the sentinel project. The fishing vessels were $15-22 \mathrm{~m}$ long and their pelagic trawl vertical opening was between 15 and $30 \mathrm{~m}$ depending on fishing conditions. The mesh size in the cod end was $12 \mathrm{~mm}$, allowing them to catch small fish in good condition.

In the Bay of Biscay, spawning sites of anchovy and sardine are spatially distinct (Bellier et al., 2007). Anchovy spawning habitats are located in coastal waters, associated with river 
116 plumes (in front of the Gironde and Adour estuaries), and sometimes occur at the shelf break

117 (Motos et al., 1996; Bellier et al., 2007; Planques et al., 2007; Petitgas et al., 2013). In

118 contrast, sardine spawning sites are frequently fragmented and cover a larger area than for

119 anchovy (Bellier et al., 2007). Thus, two key areas were selected according to the anchovy life

120 cycle: i) an area off the Gironde estuary close to $45^{\circ} 30^{\prime} \mathrm{N} 1^{\circ} 30^{\prime} \mathrm{W}$ which is a recurrent

121 spawning and nursery area observed during PELGAS surveys in spring and ii) a coastal area

122 in southern Brittany close to $47^{\circ} 30^{\prime} \mathrm{N}$ and $3^{\circ} 30^{\prime} \mathrm{W}$ where the major commercial fishery takes

123 place in autumn (Fig. 1). The commercial vessels visited both sites at least 5 times a year to

124 check for the presence of anchovy and/or sardine and to assess their biological state.

125 For each sentinel survey, the commercial fishing vessel was equipped with a Simrad

126 (Kongsberg Simrad AS, Kongsberg, Norway) EK60 split-beam echosounder of $70 \mathrm{kHz}$,

127 operated by a scientific observer to guarantee the quality of data acquisition. The transducer

128 was installed looking vertically downwards in a towed body and attached to the side of the

129 vessel. The ping rate was adjusted for the bottom depth from $0.3 \mathrm{~s}$ to $0.5 \mathrm{~s}$ between $20 \mathrm{~m}$ and

$130100 \mathrm{~m}$ depth. The equipment was previously calibrated in a tank in the laboratory using

131 standard procedures (Foote et al., 1987).

132 The strategy of the sentinel surveys was based on making best use of the knowledge of

133 fishermen about their traditional fishing areas, fishing seasons, likelihood of fish presence and

134 their behavior. This was combined with historical scientific knowledge. Within the target

135 areas, the sampling strategy was opportunistic. The captain would locate aggregations of fish

136 based on his best judgment. The scientist onboard would then set up a small grid of transects

137 perpendicular to the coast and separated by 10 nautical miles (Fig. 1). This area would then be

138 surveyed acoustically based on this design. Biological samples would be taken from trawl

139 hauls identifying any important echotraces while on transect. 
140 To complete the series, the research surveys PELGAS, conducted in spring on board RV

141 Thalassa, were also taken into account in May 2009, 2010 and 2011 (Table 1). Commercial

142 vessels played a role in the scientific surveys in a "consort" role. Pair trawlers accompanied

143 RV Thalassa to increase fishing capacity and efficiency and thus identification of echotraces,

144 in particular from the near surface and in shallow waters. The two key areas for the sentinel

145 surveys are included in the PELGAS surveys which covered the entire French plateau, from

146 the Spanish coast to $48^{\circ} \mathrm{N}$ and from the coast to the shelf break. The main objective of the

147 PELGAS surveys is to provide an annual acoustic abundance index for anchovy and sardine

148 (ICES, 2013). During the PELGAS surveys, acoustic data are only collected by RV Thalassa

149 and biological samples are collected by Thalassa or the consort commercial vessels. The

150 anchovy and sardine data of the sentinel surveys in spring can therefore be put in the larger

151 context of their full distribution range as provided by the PELGAS consort surveys. The

152 PELGAS survey used a grid of parallel transects separated by12 nautical miles perpendicular

153 to the coast. PELGAS consort commercial vessels sailed the transects at 8 knots and carried

154 out fishing operations on request. Their pelagic trawl had often a higher vertical opening (up

155 to $35 \mathrm{~m}$ ) but the cod end mesh size was similar to that used on RV Thalassa (12 $\mathrm{mm})$.

\section{2.2. Data analysis}

157 For acoustic data, the same analysis was applied to the PELGAS and sentinel survey data. The

158 echo energies were expressed as nautical area scattering coefficients (NASC, $\mathrm{m}^{2} \cdot \mathrm{nm}^{-2}$ ) per

159 elementary sampling distance unit (ESDU) (MacLennan et al., 2002). For processing, the

160 ESDU size was fixed to one nautical mile. Echotraces were ascribed to species based on

161 pelagic trawl hauls. The combination of the acoustic data with biological data allows us to

162 convert acoustic backscatter into fish abundance by species (Simmonds and MacLennan,

163 2005; Doray et al., 2010). The resulting data are density of fish in weight per square nautical 
164 mile. These processed data were plotted on maps using ArcView GIS to examine the spatial

165 occupation of anchovy and sardine within studied areas.

166 For biological data, a random sample of each species was measured to determine the length

167 distribution in $0.5 \mathrm{~cm}$ classes for anchovy and sardine and up to 5 otoliths were collected by

168 length class for age determination. In addition, annual growth increments between winter

169 rings were measured using a digital camera installed on the binocular and using the image

170 analysis software Visilog (V. 5.4.). Growth increments were measured along the major

171 (longitudinal) axis of the otolith from the nucleus to winter rings. Increments corresponding to

172 the growth of fish between birth and the first winter were measured and noted R1 for age 1

173 fish. For age 2 fish, increments between birth and second winter were noted R2 and, R2-R1

174 represented the growth of fish between the first and the second winter (Petitgas et al., 2012).

175 Fish were grouped into size categories (40 individuals): 3 for anchovy ("small" when length

176 was less than $100 \mathrm{~mm}$, "medium" between 100 and $140 \mathrm{~mm}$, and "large" when length was

177 more than $140 \mathrm{~mm}$ ) and 4 for sardine, (the same than for anchovy for the 2 smallest and

178 "large" between 140 and $180 \mathrm{~mm}$ and "very large" when length was more than $180 \mathrm{~mm}$ ). Four

179 parameters were estimated for each individual: length $\mathrm{L}(\mathrm{mm})$, wet mass $\mathrm{M}_{\mathrm{W}}(\mathrm{g})$, dry mass

$180 \quad \mathrm{M}_{\mathrm{D}}(\mathrm{g})$ and age. To get dry mass, the fish were oven-dried at $85^{\circ} \mathrm{C}$ to near constant mass $(24-$

$18172 \mathrm{~h})$.

182 Fish condition was estimated from individual length/weight measurements. Many authors

183 define an animal's condition as the energy capital accumulated in the body (i.e. fat reserves)

184 and it refers to an animal's health, quality or vigour and fitness (Peig and Green, 2009;

185 McPherson et al., 2011). Many relevant studies have used several morphometric or energetic

186 indices as proxies of the condition of the fish without consensus on the best option (Jones et 
188 2011). In this study, two metrics were used to define the fish condition:

189 i) a morphometric index, called the "Scaled mass index" $\left(\widehat{M}_{i}\right)$ (Peig and Green 2009, 2010).

190 Recently used for fish (Maceda-Veiga et al., 2014), this index standardizes mass to a specific

191 fixed body length based on the scaling relationship between mass and length using the

192 equation:

$$
\widehat{\mathrm{M}}_{\mathrm{i}}=\mathrm{M}_{\mathrm{Wi}}\left[\frac{\mathrm{L}_{0}}{\mathrm{~L}_{\mathrm{i}}}\right]^{\mathrm{b}_{\mathrm{SMA}}}
$$

194

195

196

where $M_{w i}$ is the wet body mass $(\mathrm{g})$ and $L_{i}$ the total length $\mathrm{L}(\mathrm{mm})$ of individual $i ; b_{S M A}$ is the scaling exponent obtained by the standardised major axis (SMA) regression on $\ln$-transformed weight and length values. Model II Regression in R 3.0.3 was used to determine the slope of the fitted line (i.e $b_{S M A}$ ) (Legendre, 2008). $\mathrm{L}_{0}$ was an arbitrary value of L (e.g. the arithmetic mean value for the population under study) (Peig and Green, 2009).

ii) a bioenergetic index, the "energy content" $\left(E_{D}\right)$, often used to measure fish growth and food consumption (Hartman and Brandt, 1995; Wuenschel et al., 2006; Tirelli et al., 2006; Dubreuil et Petitgas, 2009; Zhang et al., 2011; Rosa et al., 2010) to understand the energy allocation strategies of species. Dubreuil et al. (2009) established the relationship between the energy density $\left(E_{D} \mathrm{~kJ}\right.$ wet mass $\left.^{-1}\right)$ and the fish dry mass $\left(M_{D}\right)$ expressed as a percentage $\left(\% \mathrm{M}_{\mathrm{D}}=100 \mathrm{M}_{\mathrm{D}} \mathrm{M}_{\mathrm{W}}^{-1}\right)$ for anchovy of the Bay of Biscay:

$$
\mathrm{E}_{\mathrm{D}}\left(\mathrm{kJ} \mathrm{g}^{-1} \mathrm{M}_{\mathrm{W}}\right)=0.41 \times \% \mathrm{M}_{\mathrm{D}}-4.94(2)
$$

No such relationship is available for sardine in the Bay of Biscay. Yet, as energy density is correlated to $\% \mathrm{M}_{\mathrm{D}}$ and $\% \mathrm{M}_{\mathrm{D}}$ is inverse of $\% \mathrm{M}_{\mathrm{C}}$ (water content in $\%$ ), $\% \mathrm{M}_{\mathrm{D}}$ or $\% \mathrm{M}_{\mathrm{C}}$ both alike can be considered as proxy of energy density for sardine. 
209 Samples for energy content were available from the sentinel surveys only. To test for

210 significant differences in the biological parameters across seasons and areas we used a

211 Kruskal Wallis test (0.05) followed by a multiple comparison test (Kruskal et Wallis, 1952).

\section{Insert Fig. 2}

\section{3. Results}

2143.1 abundance and spatial distribution

215 Density per ESDU maps (Fig. 2) were produced for both species in the two key areas from the 216 sentinel surveys, and from the PELGAS surveys. They corresponded to eight successive 217 snapshots of the geographic distributions and relative density from May 2009 to May 2011.

218 No survey was organized in February 2010 due to bad weather conditions. Additional 219 information was considered with two indices (Table 2). The first one (AI, in tons) is the sum 220 of densities per ESDU which can be considered as an abundance index, representative of the 221 abundance of fish observed in the key area at the time of the survey. The second index $(\mathrm{n}+)$ is 222 the number of ESDUs where the fish were observed. It can be considered as a distribution 223 index (dispersion/concentration) of the fish in the key area. These indices are very variable 224 from one survey to the other. Table 2 shows for instance that anchovy was more abundant but more dispersed in April 2010 than in July (from 981 to 230 tons) in Gironde area (from 148 to 111 for $n+)$. Anchovy was also abundant in coastal waters of the southern Brittany area in

227 July. Therefore, these two indices cannot be representative of the total stock abundance, but 228 only of the presence/absence in the key area at the survey period.

\section{Insert Table 2 and Fig. 3}

230 However, it is possible from the observations to describe the seasonal movement patterns for 231 each species, their schooling behavior, and their life history stage (age, sexual maturity, 
232 growth or condition). The densest aggregations of anchovy were observed in the Gironde area 233 (Fig. 2), in shallow waters (from 20 to $50 \mathrm{~m}$ of bottom depth) and organized in small schools 234 (less than $5 \mathrm{~m}$ high) $15 \mathrm{~m}$ above the bottom (Fig. 3(a)). Anchovy were often mixed with other 235 pelagic species and were observed as thick and dense layers of small schools (Fig. 3(b)). In 236 winter, anchovy seemed to be located further offshore beyond the $60 \mathrm{~m}$ isobath (Fig. 2) partly 237 mixed with sardine (Fig. 3(a)). On the echograms, sardine schools appeared dense more than $2385 \mathrm{~m}$ high (Fig. 3(a)). Further investigations of shoal characterization would be required to 239 quantify size, shape and vertical distribution of aggregations but these structures are very 240 similar to that observed by Massé et al. (1996).

241 3.2. Monitoring of recruitment

\section{$242 \quad$ From length and age distribution}

243 Among the 8 surveys (3 PELGAS surveys and 5 sentinel surveys), 2879 individual anchovies 244 and 2308 individual sardines were sampled for length and age determination.

245 The biological materials collected allowed the monitoring of length distributions (Fig. 4(a) 246 and Fig. 5(a)) and demographic structures (Fig. 4(b) and Fig. 5(b)) of anchovy and sardine in 247 the two key areas. Proportion of age 0 and 1 in each area and their respective length modes 248 allowed us to depict the settlement of year class strength in the two areas.

\section{Insert Fig. 4 and Fig. 5}

250 In the case of anchovy for instance, small fish (length from 7.5 and $13 \mathrm{~cm}$ ) are always 251 predominant in Gironde area whereas large individuals (from 14 to $19 \mathrm{~cm}$ ) appear each year 252 in summer and autumn in southern Brittany (Fig 4(a)). Looking at age distribution (Fig 4(b)), 253 age 0 appears in the 2 areas in December 2009 and can be monitored during the 3 following 
254 surveys as age 1 . In 2010 , there is no survey in winter, but age 0 can already be seen in

255 September 2010.

\section{Insert Table 3}

257 In general, sardines are larger in southern Brittany in 2010 and smaller in the Gironde area 258 (Fig. 5(a)), where smaller fish (mean length between 13.5 and $17.9 \mathrm{~cm}$ ) were observed in 259 December 2009, April, May and September 2010 and May 2011 (Table 3). These were 260 mainly from the 0 and 1 groups (Fig. 5(b)). Nevertheless, the length and age distributions of 261 sardine are more variable from one survey to another than for anchovy.

\section{Insert Fig. 6}

\section{$263 \quad$ From otolith analysis}

264 In spring (May), R1 values (growth at age-0 before first winter) are similar in both areas (Fig. 265 6). But in other seasons and in summer in particular, values for the southern Brittany area are 266 systematically greater than those for the Gironde area, indicating that only those individuals 267 which grew faster at the beginning of their life are located in the northern habitats. R2-R1 268 values (growth between first and second winter) confirm this pattern (Fig. 6).

\section{Insert Table 4 and Table 5}

\subsection{Indices of condition}

271 Three indices of condition are considered: i) the scaled mass index $\widehat{M}_{i}$, ii) the energy density $272 \mathrm{E}_{\mathrm{D}}$ and iii) the percent dry mass $\% \mathrm{M}_{\mathrm{D}}$. The indices were estimated for anchovy and sardine 273 specimens whose length ranged from 6.5 to $20 \mathrm{~cm}$ and from 7.5 to $25 \mathrm{~cm}$, respectively. The 274 indices differed significantly between surveys (Kruskal-Wallis, $p<0.05$ ) with minimum

275 value in winter for $\widehat{M}_{i}$ and in April for $\mathrm{E}_{\mathrm{D}}$ and $\% \mathrm{M}_{\mathrm{D}}$ (Tables 3, 4, 5 and Fig. 7, Fig. 8). For 
these latter indices, higher values were detected during July and/or September 2010. A

277 significant difference was also found between the two areas (Kruskal-Wallis, $\mathrm{p}<0.05$ ).

\section{Insert Fig. 7 and Fig. 8}

\section{4. Discussion}

280 The sentinel pilot study demonstrates that it is possible to conduct a scientifically sound 281 research program, using the expertise of both fishermen and scientists. Fishermen were 282 involved in each phase of the project; developing sampling protocol, locating fish 283 aggregations and collecting biological data, making it a truly collaborative fisheries research 284 program (Yochum et al., 2011; Johnson and van Densen, 2007).

285 The objective of this experiment was to see if it was possible to develop useful indicators to 286 monitor sardine and anchovy populations. A secondary objective was to determine if this was 287 feasible using an approach consisting of short and seasonally repeated surveys, in specific key 288 target areas using commercial vessels, taking advantage of the skills and knowledge of the 289 fishermen. Because of meteorological conditions, it was often necessary to adjust the schedule 290 of these short surveys and acoustic data collection was sometimes challenging onboard such 291 small vessels. Nevertheless, several indicators were successfully calculated: acoustic index of 292 presence of each species by area and their length and age distributions, condition index and 293 growth index.

294 Surveys on commercial vessels targeting specific key areas, using local fishermen's 295 knowledge and supported by research acoustic systems and expertise, have been attempted 296 previously for stock assessment (O’Driscoll and Macauley, 2005; Ressler et al., 2009;

297 Barbeaux and Fraser, 2009; Honkalehto et al., 2011). Their studies demonstrated that such 298 cooperation was a promising way of monitoring species abundance in small scale areas. In our 299 case, the local abundance indices by area provided by sentinel surveys were not representative 
of the global stock abundance. Nevertheless, the sentinel surveys were well-suited for

301 monitoring anchovy, in terms of the strength and arrival in coastal waters of the new year

302 class strength. This monitoring showed that 0 group appearance progresses from Gironde to

303 southern Brittany (in July and December, respectively), and is consistent with what is already

304 known about the spawning season, which begins in the south of the Bay of Biscay and ends in

305 southern Brittany (Bellier et al., 2007). The sentinel surveys were not as successful for

306 monitoring sardine, which can be explained by the larger spatial distribution of sardine

307 spawning compared to that of anchovy; a more appropriate key area and more surveys might

308 be necessary for sardine. Also, unlike the anchovy spawning season, which is mainly

309 concentrated in spring, the spawning season of sardine is spread over much of the year with

310 two distinct peaks in spring and autumn (Arbault and Lacroix, 1971, 1977; Bellier et al.,

311 2007).

312 The data collected by the sentinel surveys allowed us to monitor the seasonal evolution of

313 biological parameters (growth, energy) as well as differences between northern and southern

314 habitats. The measured values of the biological indices agreed with values already observed

315 for anchovy and sardine in the Bay of Biscay and in the Mediterranean (Maceda-Veiga et al.,

316 2014; Spitz et al., 2010; Dubreuil et Petitgas, 2009; Tirelli et al., 2006; Rosa et al., 2010). The

317 sentinel surveys thus show potential to monitor the key biological processes, which determine

318 population health, if not global abundance. To maximize the suitability of indicators, it would

319 be necessary to target key seasons each year, such as summer (August - September) and

320 winter (December to February) taking into account that scientific surveys already occur in

321 spring and autumn.

322 Last but not least, exchanges between fishermen and scientists working together on the

323 sentinel survey project increased and encouraged mutual understanding and interest in 
324 obtaining integrated knowledge on the biology of the resources and their management

325 strategies.

\section{Acknowledgements}

327 We are particularly grateful to the commercial vessels captains and crews who voluntary

328 participated to the sentinel surveys for their efficient work and fair exchange of knowledge.

329 We sincerely thank Patrick Grellier, Patrick Lespagnol, Estelle Soulet and Muriel Lissardy for

330 their help and for sample and data processing. We also thank the scientists and crew on board

331 RV Thalassa during PELGAS surveys. We are also grateful to the two reviewers and the

332 editor for their useful comments on the submitted manuscript. This study was supported from

333 National and European funds and relied on a partnership with Ifremer, the National

334 Committee of Marine Fisheries (CNPMEM) and the Direction of Marine Fisheries and

335 Aquaculture (DPMA). 
Allain, G., Petitgas, P., Lazure, P., 2001. The influence of mesoscale ocean processes on anchovy (Engraulis encrasicolus) recruitment in the Bay of Biscay estimated with a three-dimensional hydrodynamic model. Fish. Oceanogr. 10: 151-163.

Allain, G., Petitgas, P., Lazure, P. 2007. The influence of environment and spawning distribution on the survival of anchovy (Engraulis encrasicolus) larvae in the Bay of Biscay (NE Atlantic) investigated by biophysical simulations. Fish. Oceanogr. 16, 506-514.

Arbault, S., and Lacroix, N., 1971. Aires de ponte de la sardine, du sprat et de l'anchois dans le golfe de Gascogne et sur le plateau celtique. Résultats de 6 années d'études. Rev. Trav. Inst. Pêches Marit. 35, 35-56.

Arbault, S., and Lacroix, N., 1977. CEufs et larves de clupéidés et engraulidés dans le golfe de Gascogne (1969-1973). Distribution des frayères. Relations entre les facteurs du milieu et la reproduction. Rev. Trav. Inst. Pêches Marit. 41, 227-254.

Barbeaux, J., Fraser, D., 2009. Aleutian Islands Cooperative Acoustic Survey Study for 2006. U.S. Dep. Commer., NOAA Tech. Memo. NMFS-AFSC-198, 91 p.

Bellier, E., Planque, B., and P., Petitgas, 2007. Historical fluctuations in spawning location of anchovy (Eugraulis encrasicolus) and sardine (Sardina pilchardus) in the Bay of Biscay during 1697-73 and 2000-2004. Fish. Oceanogr. 16(1), 1-15.

Boyra, G., Martínez, U., Cotano, U., Santos, M., Irigoien, X., Uriarte, A., 2013. Acoustic surveys for juvenile anchovy in the Bay of Biscay: abundance estimate as an indicator of the next year's recruitment and spatial distribution patterns. ICES J. Mar. Sci. 70, 1354-1368.

Borja, A., Uriarte, A., Valencia, V., Motos, L., Uriarte A. 1996. Relationships between anchovy (Engraulis encrasicolus L.) recruitment and the environment in the Bay of Biscay. Sci. Mar., 60(2), 179-192.

Borja, A., Fontan, A., Saenz, J., Valencia, V., 2008. Climate, oceanography, and recruitment: the case of Bay of Biscay anchovy (Engraulis encrasicolus). Fish. Oceanogr. 17, 477493.

Doray, M., Massé, J., Petitgas, P., 2010. Pelagic fish stock assessment by acoustic methods at Ifremer. R. INT. DOP/DCN/EMH 10-02, 17 p.

Fernandes, J., Irigoien, X., Goikoetxea, N., Lozano, J., Inza, I., Pérez, A., Bode, A., 2010. Fish recruitment prediction, using robust supervised classification methods. Ecol. Mod. 221: 338-352.

Dubreuil, J., Petitgas, P., 2009. Energy density of anchovy Engraulis encrasicolus in the Bay of Biscay. J. Fish. Biol. 74, 521-534. 
Foote, K., Knudsen, H. P., and Vestnes, G. 1987. Calibration of Acoustic Instruments for Fish Density Estimation: A Practical Guide. International Council for the Exploration of the Sea, Copenhagen, Denmark.

Froese, R., 2006. Cube law, condition factor and weight-length relationships: history, metaanalysis and recommendations. J. Appl. Ichthyol. 22, 241-253.

Hartman, K.J., Brandt, S.B., 1995. Estimating energy density of fish. T. Am. Fish. So. 124, 347-355.

Honkalehto, T., H. Ressler, P., H. Towler, R., and D. Wilson, C., 2011. Using acoustic data from fishing vessels to estimate walleye pollock (Theragra chalcogramma) abundance in the eastern Bering Sea. Can. J. Fish. Aquat. Sci. 68, 1231-1242.

Huret, M., Petitgas, P. and Woillez, M., 2010. Dispersal kernels and their drivers captured with a hydrodynamic model and spatial indices: a case study on anchovy (Engraulis encrasicolus) early life stages in the Bay of Biscay. Prog. Oceanog. 87, 6-17.

ICES, 2006. Report of the Working Group on Acoustic and Egg Surveys for Sardine and Anchovy in ICES Areas VIII and IX (WGACEGG). ICES CM 2006/LRC: 18.

ICES, 2007. Report of the Working Group on the assessment of mackerel, horse mackerel, sardine and anchovy (WGMHSA). ICES CM2007/ACFM: 31.

ICES, 2010. Life-cycle spatial patterns of small pelagic fish in the Northeast Atlantic. ICES Cooperative Research Report, No. 306, 94pp.

ICES, 2013. Report of the Working Group on Acoustic and Egg Surveys for Sardine and Anchovy in ICES Areas VIII and IX (WGACEGG). ICES CM 2013/SSGESST: 20.

ICES, 2013. Report of the Working Group on Southern Horse Mackerel, Anchovy and Sardine (WGHANSA). ICES CM 2013/ACOM: 16, 752 pp.

Johnson, T.R., and van Densen, W.L.T., 2007. The benefits and organization of cooperative research for fisheries management. ICES J. Mar. Sci. 64, 834-840.

Jones, R.E., Petrell, R.J., Pauly, D., 1999. Using modified length-weight relationships to assess the condition of fishes. Aquacult. Eng. 20, 261-176.

Kotrschal, A., Fischer, B., Taborsky, B., 2011. A Noninvasive method to determine fat content in small fish based on swim bladder size estimation. J. Exp. Zool. A. Ecol. Genet. Physiol. 315(7), 4008-4015.

Kruskal, W. H. and W. A. Wallis, 1952. Use of ranks on one-criterion variance analysis. J. Amer. Statist. Assoc., 47, 583-621. Addendum: Ibid. (1953), 907-911 (5.6).

Legendre, P., 2008. lmodel2: Model II regression. R package version 1.7-2. 
Maceda-Veiga, A., Green, A.J., De Sostoa, A., 2014. Scaled body-mass index shows how habitat quality influences the condition of four fish taxa in north-eastern Spain and provides a novel indicator of ecosystem health. Fresh. Biol. 59, 1145-1160.

MacLennan, D., Fernandes, P., Dalen, J., 2002. A consistent approach to definitions and symbols in fisheries acoustics. ICES J. Mar. Sci. 59, 365-369.

Massé, J., Koutsikopoulos, C., Patty, W., 1996. The structure and spatial distribution of pelagic fish schools in multispecies clusters: an acoustic study. ICES J. Mar. Sci. 53, 155-160.

McPherson, L.R., Slotte, A., Kvamme, C., Meier, S., Marshall, C.T., 2011. Inconsistencies in measurement of fish condition: a comparison of four indices of fat reserves for Atlantic herring (Clupea harrengus). ICES J. Mar. Sci. 68(1), 52-60.

Motos, L., Uriarte, A., Valencia, V., 1996. The spawning environment of the Bay of Biscay anchovy (Engraulis encrasicolus, L). Sci. Mar. 60(Suppl 2), 117-140.

O'Driscoll, R. L., and Macaulay, G. J., 2005. Using fish-processing time to carry out acoustic surveys from commercial vessels. ICES J. Mar. Sci. 62, 295 - 305.

Pecquerie, L., Petitgas, P., Kooijman, S., 2009. Modeling fish growth and reproduction in the context of the Dynamic Energy Budget theory to predict environmental impact on anchovy spawning duration. J. Sea Res. 62, 93-105.

Peig, J., Green, A.J., 2009. New perspectives for estimating body condition from mass/length data: the scaled mass index as an alternative method. Oikos 118, 1883-1891.

Peig, J., Green, A.J., 2010. The paradigm of body condition: a critical reappraisal of current methods based on mass and length. Functional Ecol. 24, 1323-1332.

Petitgas, P., Doray, M., Massé, J., Grellier, P., 2011. Spatially explicit estimation of fish length histograms, with application to anchovy habitats in the Bay of Biscay. ICES J. Mar. Sci. 68, 2086-2095.

Petitgas, P., Huret, M., Léger, F., 2011. Identifying and monitoring limiting factors of recruitment: anchovy in the Bay of Biscay. ICES CM 2011/H:11, 14 p.

Petitgas, P., Grellier, P., Duhamel, E., Huret, M., Massé, J., Doray, M., 2012. Variability and controls of otolith growth in the anchovy of the Bay of Biscay. ICES, CM-2012/J: 18.

Petitgas, P., Rijnsdorp, A.D., Dickey-Collas, M., Engelhard, G.H., Peck, M.A., Pinnegar, J.K., Drinkwater, K., Huret, M. and Nash R.D.M., 2013. Impacts of climate change on the complex life cycles of fish. Fish. Oceanogr. 22(2), 121-139.

Planque, B., Bellier, E., Lazure P., 2007. Modelling potential spawning habitat of sardine (

Sardina pilchardus) and anchovy (Engraulis encrasicolus) in the Bay of Biscay. Fish. Oceanogr. 16, 16-30. 
Rosa, R., Gonzalez, L., Broitman, B.R., Garrido, S., Santos, A. M. P., Nunes, M.L., 2010. Bioenergetics of small pelagic fishes in upwelling systems: relationship between fish condition, coastal ecosystem dynamics and fisheries. Mar. Ecol. Prog. Ser. 410, $205-$ 218.

Ressler, P.H., Fleischer, G.W., Wespestad, V.G., Harms, J., 2009. Developing a commercialvessel-based stock assessment survey methodology for monitoring the U.S. west coast widow rockfish (Sebaste sentomelas) stock. Fish. Res. 99, 63-73.

Silva, A., Skagen, D. W., Uriarte, A., Massé, J., Santos, M. B., Marques, V., Carrera, P., Beillois, P., Pestana, G., Porteiro, C., and Stratoudakis, Y. 2009. Geographic variability of sardine dynamics in the Iberian Biscay region. ICES J. Mar. Sci., 66, 495-508.

Simmonds, E.J., MacLennan, D.N., 2005. Fisheries Acoustics. Theory and Practice. Blackwell publishing, Oxford, UK.

Spitz, J., Mourocq, E., Schoen, V., Ridoux, V., 2010. Proximate composition and energy content of forage species from the Bay of Bicay: high or low quality food? ICES J. Mar. Sci. 67, 909-915.

Tirelli, V., Borme, D., Tulli, F., Cigar, M., Fonda Umani, S., Brandt, S.B., 2006. Energy density of anchovy Engraulis encrasicolus L. in the Adriatic Sea. J. Fish. Biol. 68, 982-989.

Wuenschel, M.J., Jugovich, A.R., Hare, J.A., 2006. Estimating the energy density of fish: the importance of ontogeny. T. Am. Fish. So. 135, 379-385.

Yochum, N., Starr, R.M., Wendt, D.E., 2011. Utilizing fishermen knowledge and expertise: keys to success for collaborative fisheries research. Fisheries 36, 593-605.

Zhang, B., Zhao X., Dai, F., 2011. Monthly variation in the fat content of anchovy (Engraulis japonicus) in the Yellow sea: implications for acoustic abundance estimation. Chin. J. Oceanol. Limnol. 29(3), 556-563. 
516 Fig. 1. The Bay of Biscay is located in North Atlantic along the west coast of France

517 (overview map). The two key areas in this study are indicated on the map on the right along 518 with the location of transects carried out during one of the five surveys.

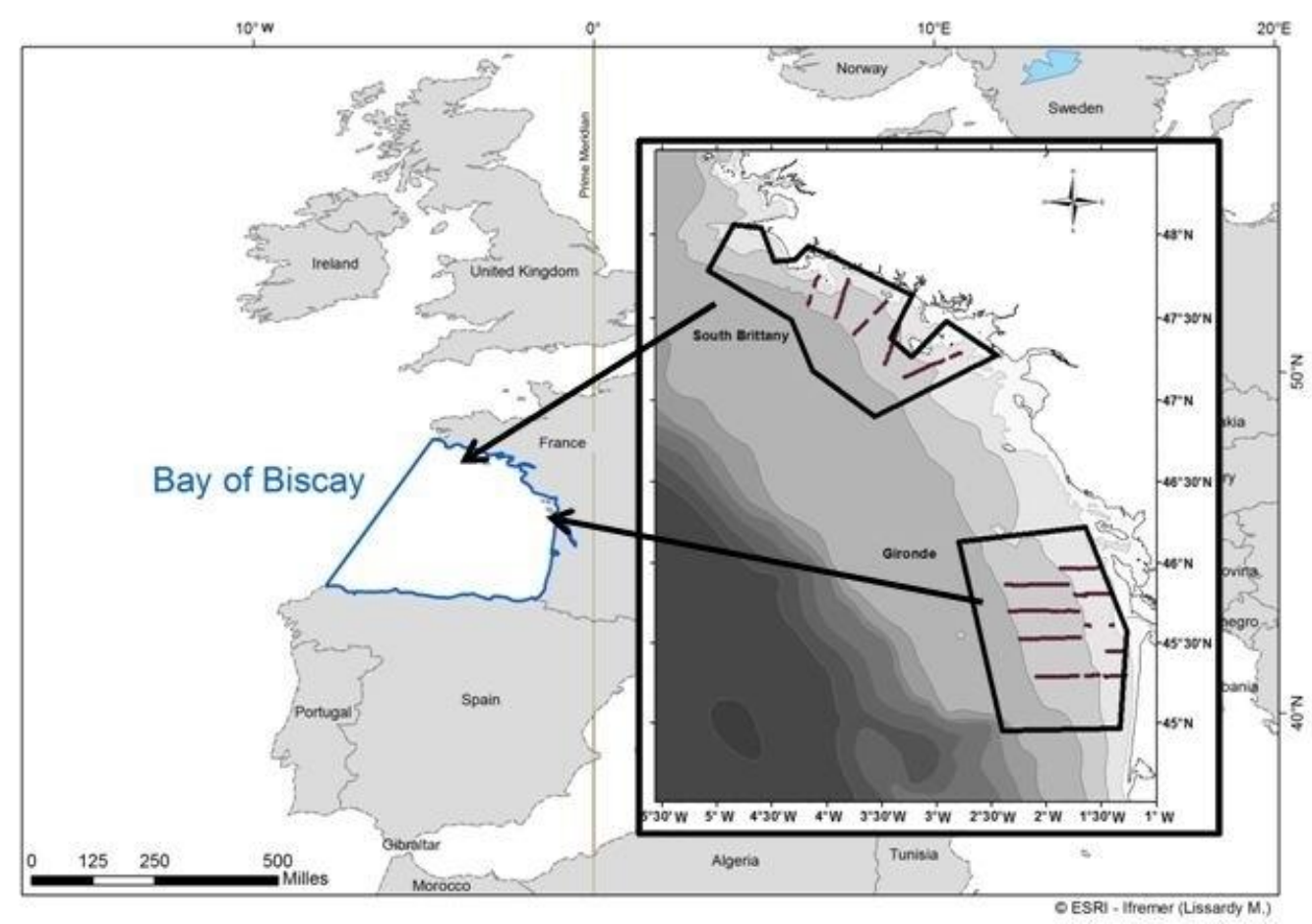


521 Fig. 2. Acoustic density of anchovy (green circles) .and sardine (blue circles) by survey in the 522 two key areas $(\mathrm{kg} \mathrm{nm})$, where the letter "P" indicates a PELGAS survey and " $\mathrm{S}$ " a sentinel 523 survey. For clarification, sardine circles were slightly shifted to avoid superimposition of 524 symbols. (For interpretation of the references to color in this figure legend, the reader is 525 referred to the web version of this article).
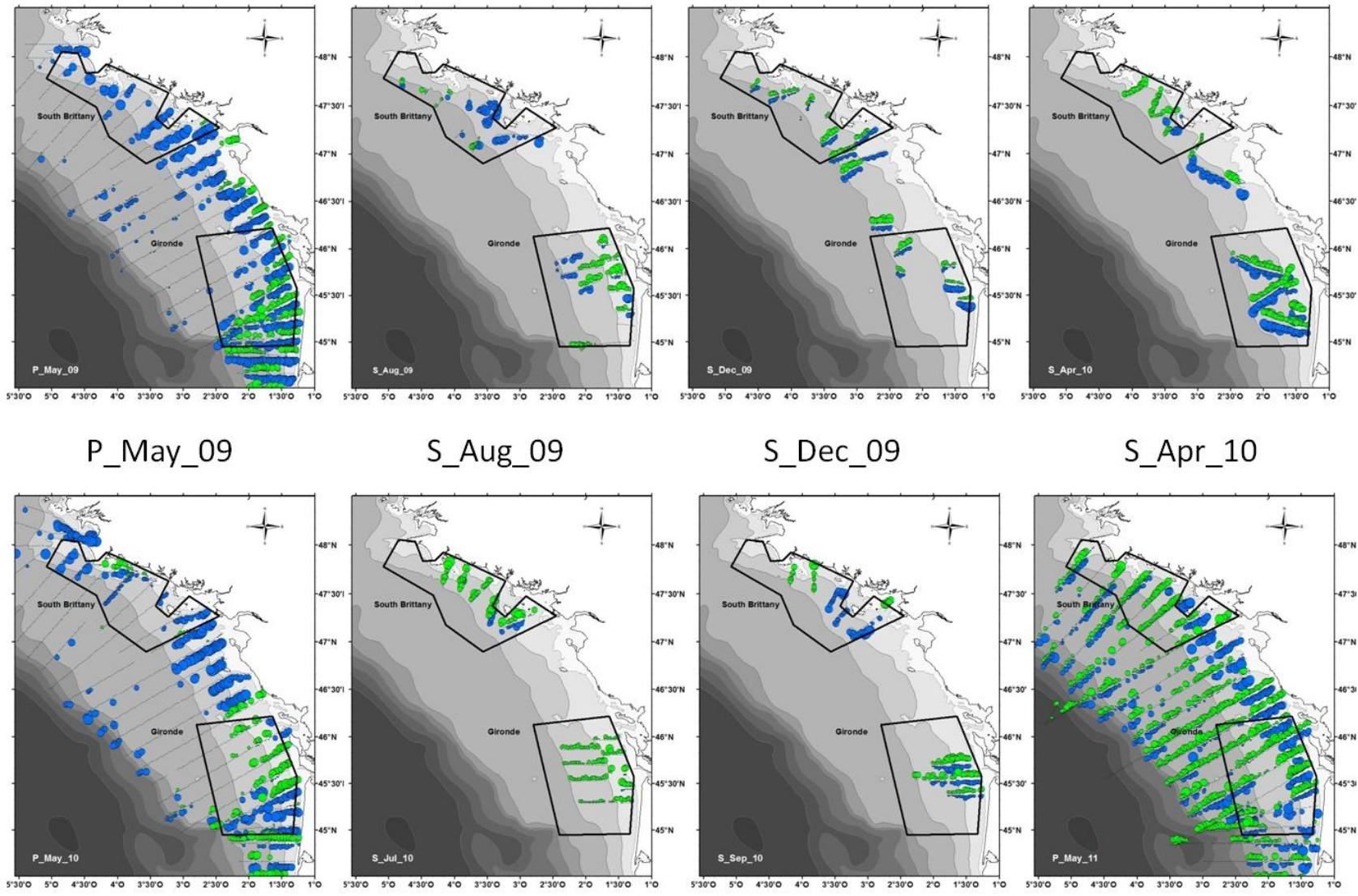

$$
\text { S_Apr_10 }
$$


528 Fig. 3. Examples of echograms obtained during sentinel surveys (a) schools of anchovy and

529 sardine in Gironde area during July 2010, (b) schools of mixed species in Gironde area during

530 September 2010.

a)

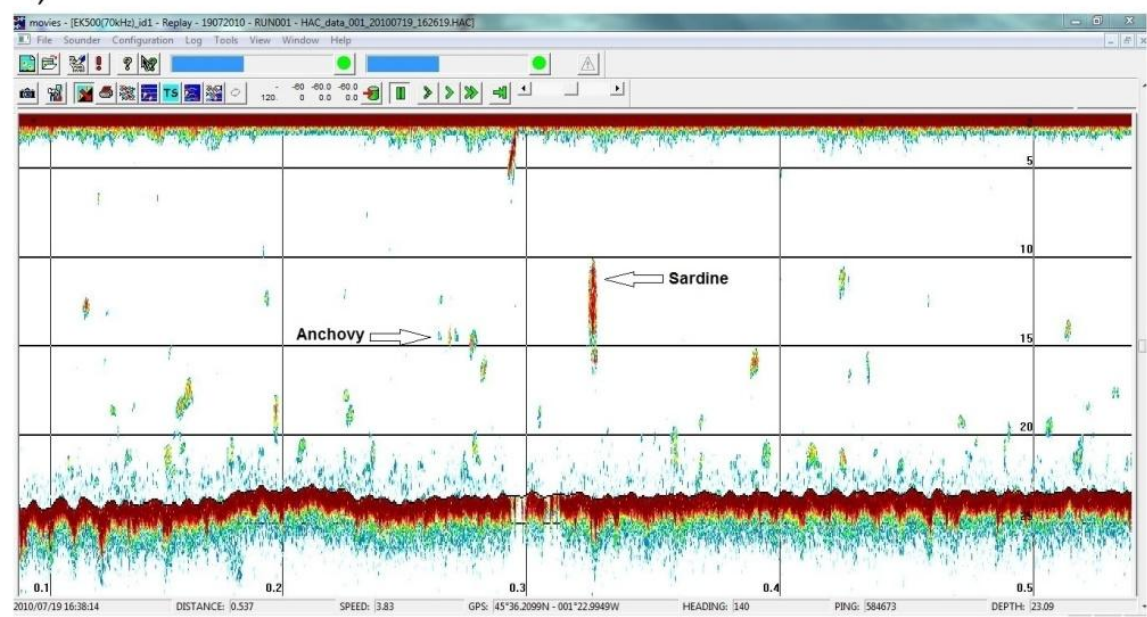

b)

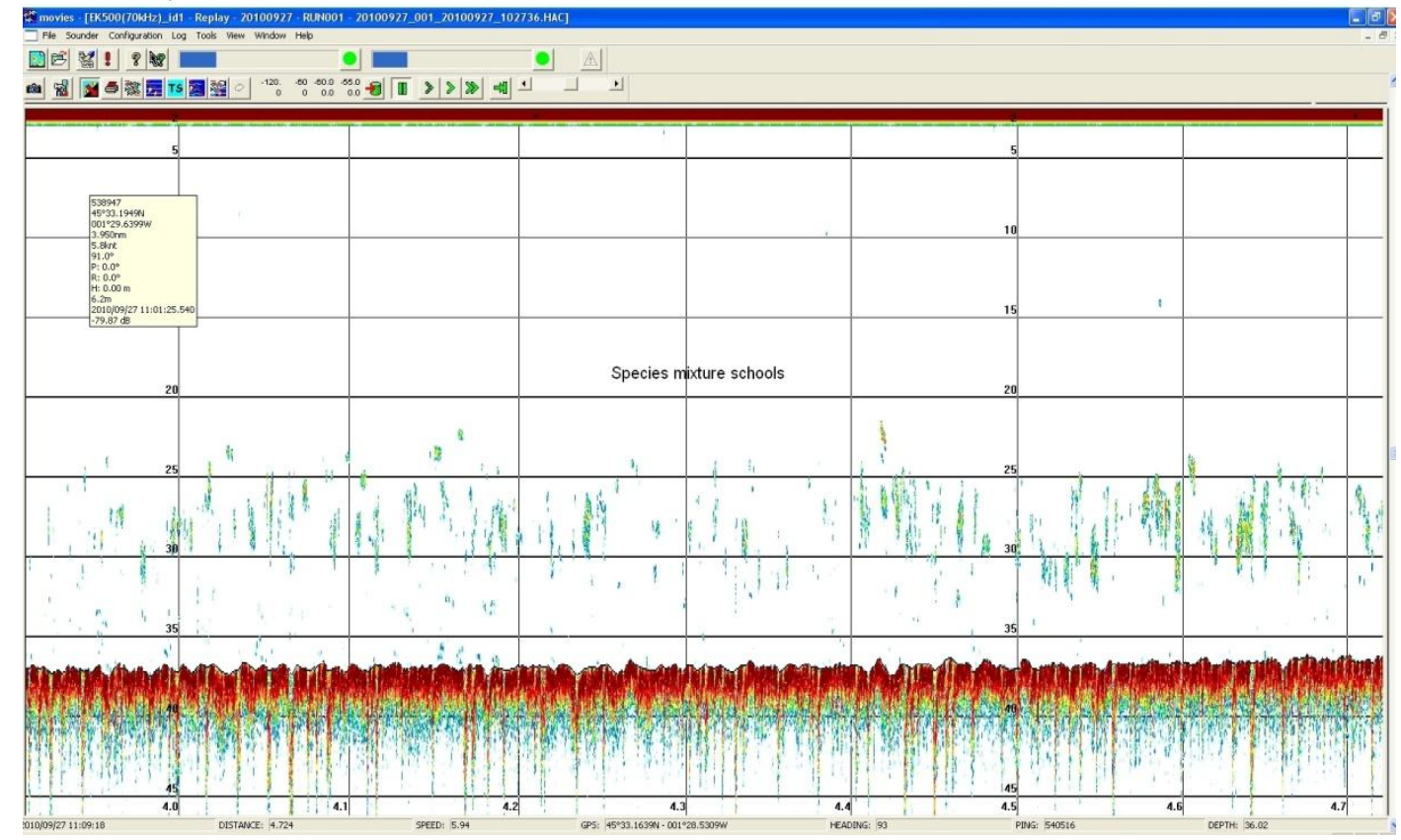


533 Fig. 4. Length distribution (a) and age distribution (b) of anchovy in\% of total number for the 534 PELGAS (P) and sentinel (S) surveys in southern Brittany (top) and Gironde (bottom) areas. 535

a)
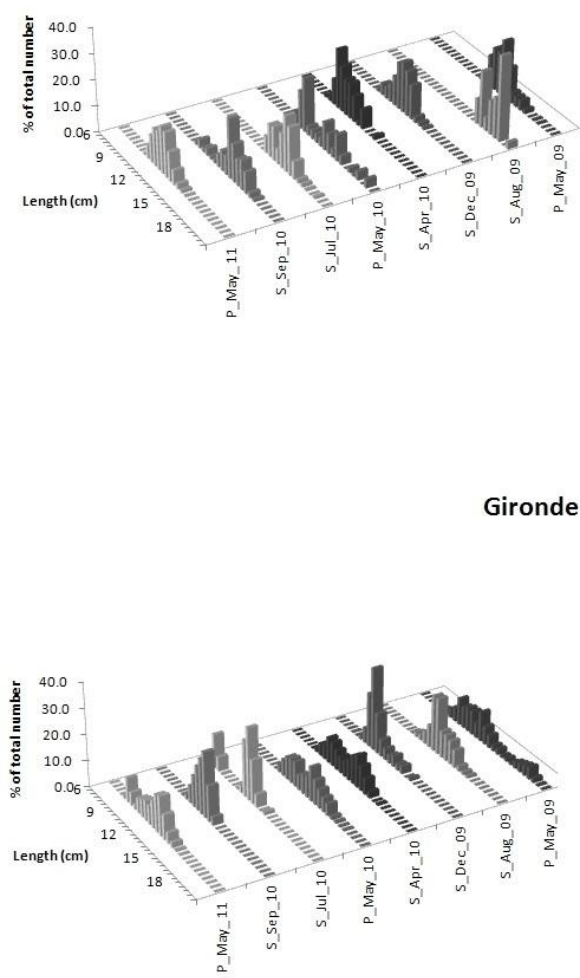

b)

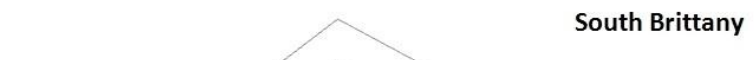

Gironde

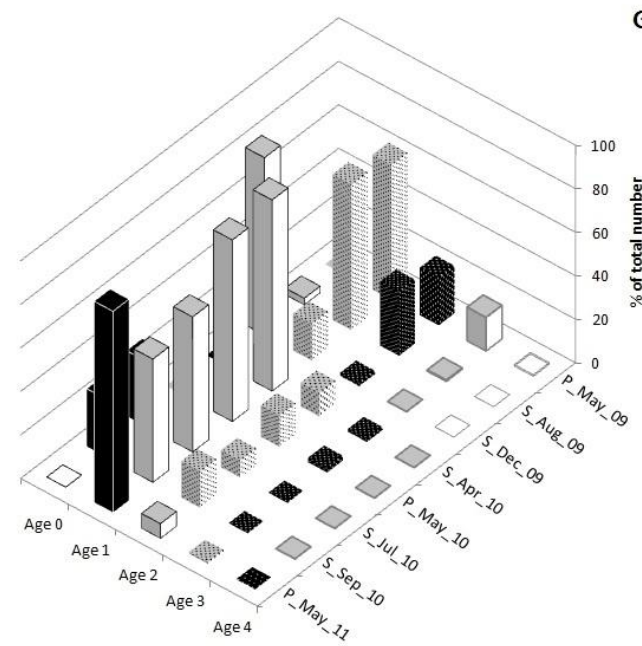


538 Fig. 5. Length distribution (a) and age distribution (b) of sardine in $\%$ of total number for the

539 PELGAS (P) and sentinel (S) surveys in southern Brittany (top) and south Gironde (bottom) areas.

a)
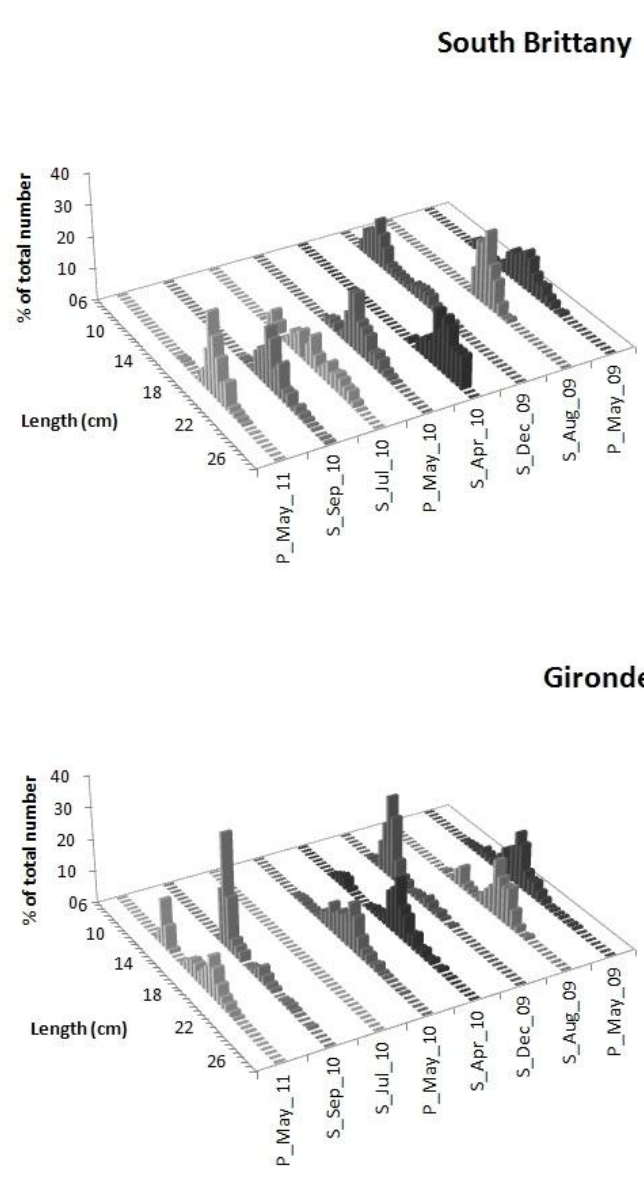

Gironde b)

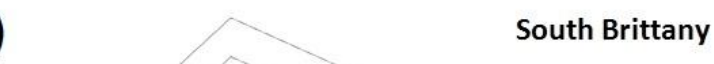


543 Fig. 6. Mean growth of anchovy between the first and the second winter measured on age 2 544 fish. R1 is indicator of the growth during the first spring/summer period and R2-R1 is 545 indicator of the growth between the first and the second winter.

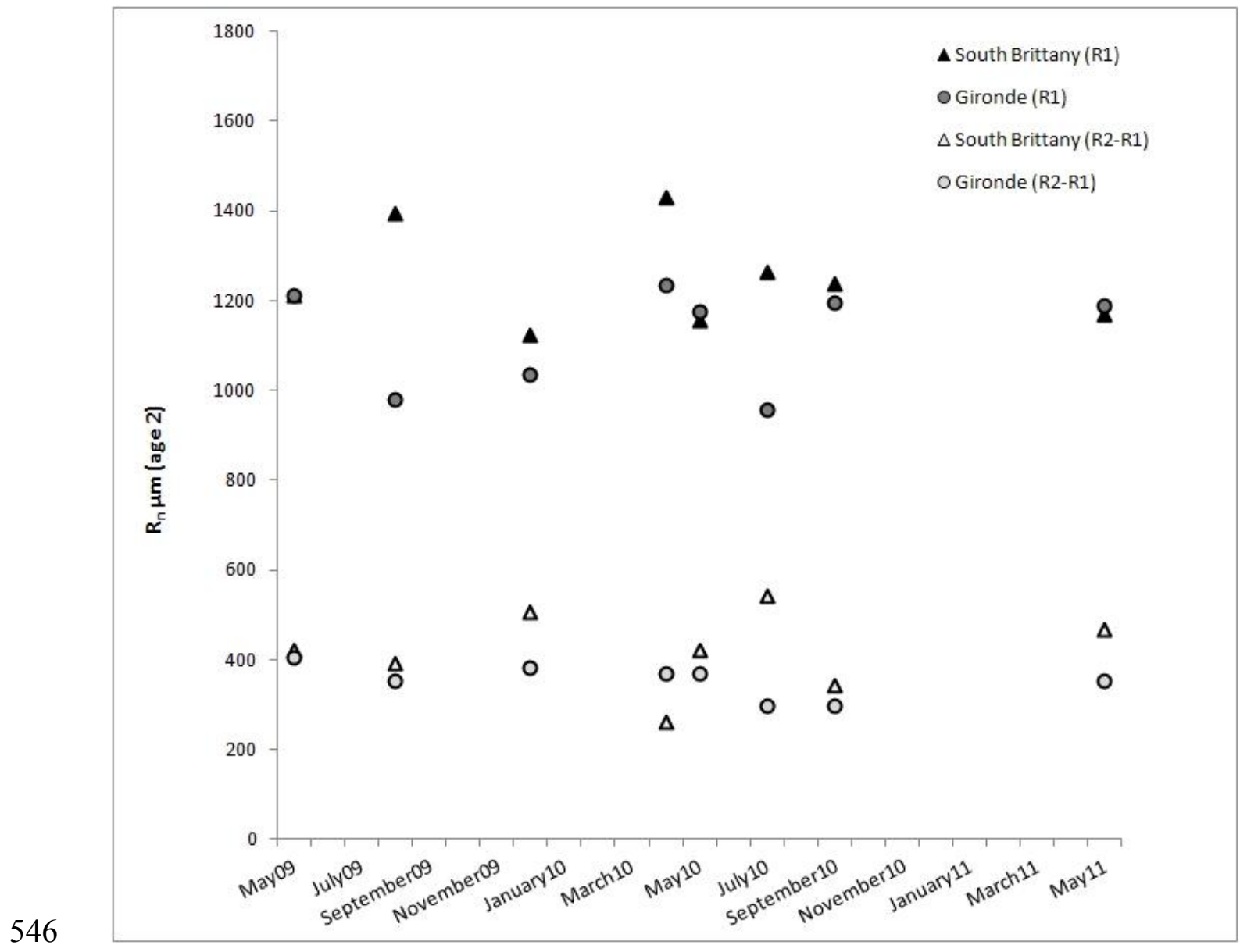


548 Fig. 7. Box plots of the scaled mass index (SMI, g) for anchovy (top) and sardine (bottom)

549 throughout the year from PELGAS and sentinel surveys in the southern Brittany and Gironde 550 areas.
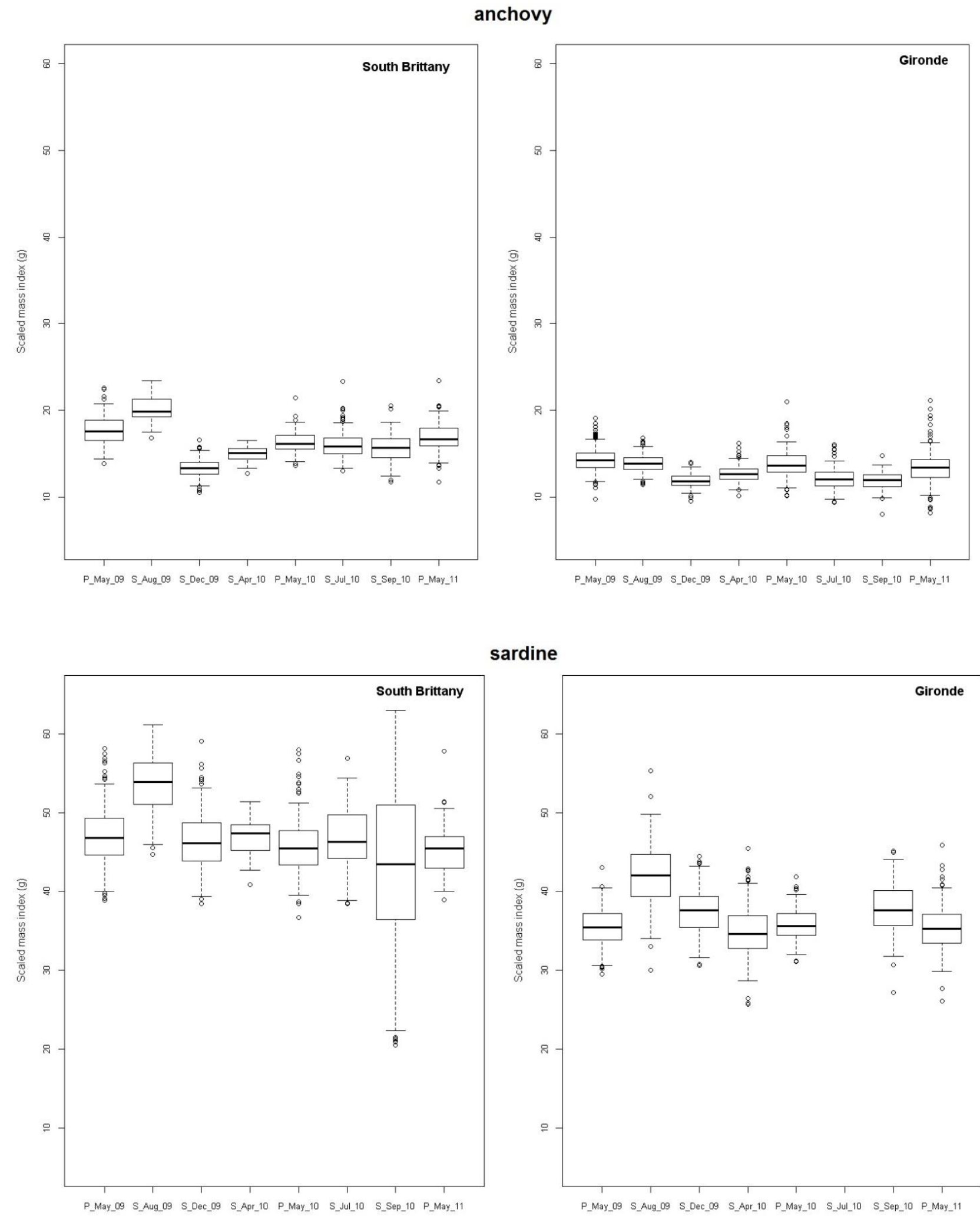

sardine

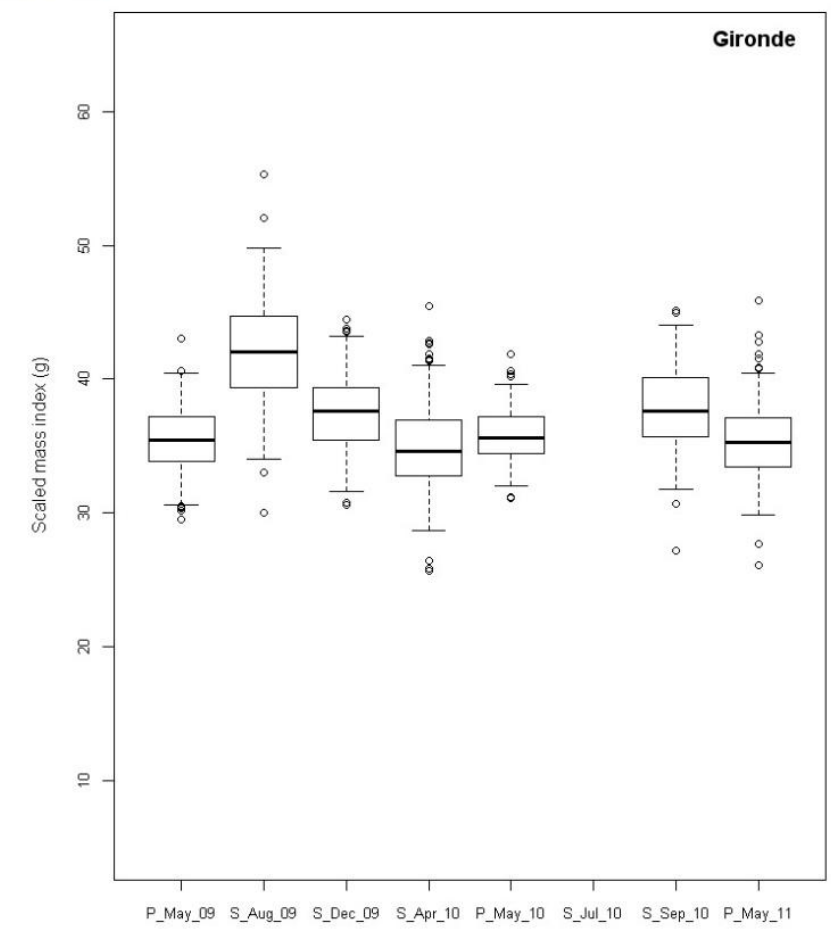


553 Fig. 8. Boxplot of the energy content ( $\left.\mathrm{E} \mathrm{kJ} \mathrm{g}^{-1}\right)$ for anchovy (top) and the percent dry mass $554\left(\% \mathrm{M}_{\mathrm{D}}\right)$ for sardine (bottom) sampled during sentinel surveys in the southern Brittany and 555 Gironde areas.
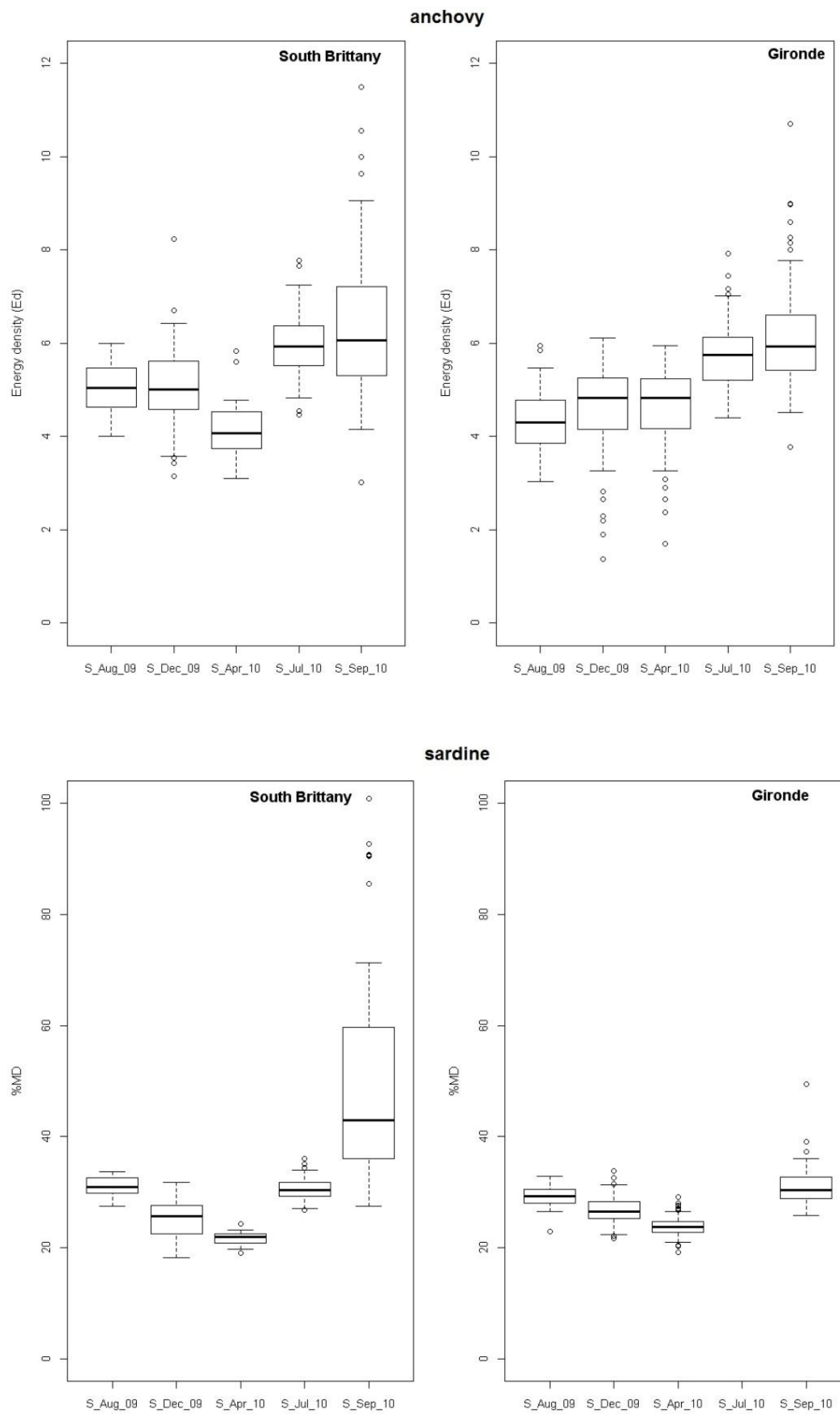

sardine

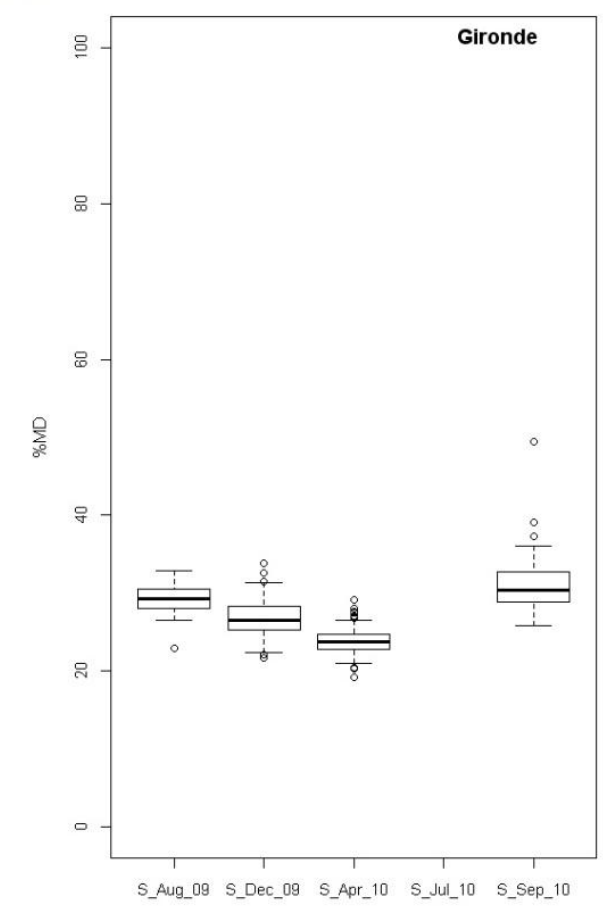


Table 1. Calendar of surveys.

\begin{tabular}{|c|c|c|c|c|c|}
\hline Survey & Codification survey & $\begin{array}{l}\text { Commercial fishing vessel } \\
\text { (size) Fishing harbour }\end{array}$ & Season & Days at sea & Number of hauls \\
\hline \multirow{2}{*}{$\begin{array}{l}\text { Consort } \\
\text { PELGAS }\end{array}$} & \multirow{2}{*}{ P_May_09 } & $\begin{array}{l}\text { Zéphyr and Carla Eglantine } \\
\text { (size: } 17.5 \mathrm{~m} \& 17.8 \mathrm{~m} \text { ) } \\
\text { La Turballe }\end{array}$ & $\begin{array}{l}26 / 04 / 2009 \text { to } \\
06 / 05 / 2009\end{array}$ & 11 & \multirow{2}{*}{55} \\
\hline & & $\begin{array}{l}\text { Magayant and Mary Christo } \\
\text { (size: } 22.8 \mathrm{~m} \& 20.6 \mathrm{~m} \text { ) } \\
\text { La Turballe }\end{array}$ & $\begin{array}{l}07 / 05 / 2009 \text { to } \\
16 / 05 / 2009\end{array}$ & 10 & \\
\hline Sentinel & S_Aug_09 & \multirow{2}{*}{$\begin{array}{l}\text { Cintharth and Marilude } 2 \\
\text { (size: } 23.3 \mathrm{~m} \& 20.2 \mathrm{~m} \text { ) } \\
\text { La Turballe }\end{array}$} & $\begin{array}{l}10 / 08 / 2009 \text { to } \\
14 / 08 / 2009\end{array}$ & 5 & 12 \\
\hline Sentinel & S_Dec_09 & & $\begin{array}{l}15 / 12 / 2009 \text { to } \\
19 / 12 / 2009\end{array}$ & 5 & 11 \\
\hline Sentinel & S_Apr_10 & $\begin{array}{l}\text { Jérémi-Simon and } \\
\text { Prométhée } \\
\text { (size: } 20 \mathrm{~m} \& 20 \mathrm{~m}) \\
\text { St Gilles Croix de vie }\end{array}$ & $\begin{array}{l}05 / 04 / 2010 \text { to } \\
10 / 04 / 2010\end{array}$ & 5 & 9 \\
\hline \multirow{2}{*}{$\begin{array}{l}\text { Consort } \\
\text { PELGAS }\end{array}$} & \multirow{2}{*}{ P_May_10 } & $\begin{array}{l}\text { Tangaroa and Magayant } \\
\text { (size: } 20.6 \mathrm{~m} \& 22.8 \mathrm{~m} \text { ) } \\
\text { La Turballe }\end{array}$ & $\begin{array}{l}26 / 04 / 2010 \text { to } \\
06 / 05 / 2010\end{array}$ & 11 & \multirow{2}{*}{46} \\
\hline & & $\begin{array}{l}\text { Morgan and Virginie } \\
\text { (size: } 19.5 \mathrm{~m} \mathrm{\&} 19.5 \mathrm{~m} \text { ) } \\
\text { Lorient }\end{array}$ & $\begin{array}{l}07 / 05 / 2010 \text { to } \\
17 / 05 / 2010\end{array}$ & 11 & \\
\hline Sentinel & S_Jul_10 & \multirow{2}{*}{$\begin{array}{l}\text { Joker and ArRaok } 2 \\
\text { (size: } 16.1 \mathrm{~m} \mathrm{\&} 15.9 \mathrm{~m} \text { ) } \\
\text { La Turballe }\end{array}$} & $\begin{array}{l}18 / 07 / 2010 \text { to } \\
23 / 07 / 2010\end{array}$ & 5 & 10 \\
\hline Sentinel & S_Sep_10 & & $\begin{array}{l}26 / 09 / 2010 \text { to } \\
30 / 09 / 2010\end{array}$ & 4 & 9 \\
\hline \multirow{2}{*}{$\begin{array}{l}\text { Consort } \\
\text { PELGAS }\end{array}$} & \multirow[b]{2}{*}{ P_May_11 } & $\begin{array}{l}\text { Arlequin } 2 \text { and Colombine } \\
\text { (size: } 19.8 \mathrm{~m} \mathrm{\&} 22.6 \mathrm{~m} \text { ) } \\
\text { La Turballe }\end{array}$ & $\begin{array}{l}27 / 04 / 2011 \text { to } \\
08 / 05 / 2011\end{array}$ & 13 & \multirow[b]{2}{*}{61} \\
\hline & & $\begin{array}{l}\text { Jérémi-Simon and } \\
\text { Prométhée } \\
\text { (size: } 20 \mathrm{~m} \& 20 \mathrm{~m}) \\
\text { St Gilles Croix de vie }\end{array}$ & $\begin{array}{l}10 / 05 / 2011 \text { to } \\
18 / 05 / 2011\end{array}$ & 9 & \\
\hline
\end{tabular}

559 
561 Table 2. Statistics of anchovy and sardine density per esdu (kg per square nautical mile) for 562 each area during sentinel surveys. $\mathrm{n}=$ number of ESDUs, mean=average $\left(\mathrm{kg}^{\mathrm{ngm}} \mathrm{nm}^{-2}\right)$, s.e. $=$ 563 standard error, sum $=$ abundance index (in tons), $\mathrm{n}+=$ number of positive ESDUs, $\max =$ 564 maximum density value $\left(\mathrm{kg} . \mathrm{nm}^{-2}\right)$.

\begin{tabular}{lllllll}
\hline Species/Area & & Aug_09 & Dec_09 & Apr_10 & Jul_10 & Sep_10 \\
\hline Anchovy/Gironde & $\mathrm{n}$ & 187 & 62 & 115 & 153 & 81 \\
& Mean \pm s.e. & $2019 \pm 494$ & $3134 \pm 833$ & $8538 \pm 1259$ & $1507 \pm 354$ & $6195 \pm 1311$ \\
& Sum & 377 & 194 & 981 & 230 & 501 \\
& $\mathrm{n}_{+}$ & 94 & 62 & 111 & 148 & 79 \\
& Max & 377482 & 194324 & 981857 & 230642 & 501821 \\
\hline Anchovy/South Brittany & $\mathrm{n}$ & 110 & 106 & 128 & 77 & 83 \\
& Mean \pm s.e. & $302 \pm 129$ & $2070 \pm 397$ & $2592 \pm 547$ & $13029 \pm 3234$ & $6302 \pm 4210$ \\
& Sum & 33 & 219 & 331 & 1000 & 523 \\
& $\mathrm{n}_{+}$ & 23 & 85 & 74 & 66 & 24 \\
& Max & 10978 & 30829 & 37321 & 145693 & 344392 \\
\hline Sardine/Gironde & $\mathrm{n}$ & 187 & 62 & 115 & 153 & 81 \\
& Mean \pm s.e. & $1116 \pm 410$ & $6287 \pm 1682$ & $25196 \pm 4181$ & $1 \pm 1$ & $1484 \pm 336$ \\
& Sum & 208 & 389 & 2900 & 184 & 120 \\
& $\mathrm{n}_{+}$ & 57 & 62 & 111 & 10 & 72 \\
& Max & 54276 & 75862 & 244595 & 76 & 19020 \\
\hline Sardine/South Brittany & $\mathrm{n}$ & 110 & 106 & 128 & 77 & 83 \\
& Mean \pm s.e. & $7835 \pm 1892$ & $927 \pm 135$ & $7560 \pm 1883$ & $729 \pm 268$ & $11317 \pm 3448$ \\
& Sum & 861 & 98 & 967 & 56 & 939 \\
& $\mathrm{n}$ & 58 & 106 & 39 & 27 & 48 \\
& Max & 128885 & 11071 & 116181 & 16486 & 176205 \\
\hline
\end{tabular}

565 
Table 3. Mean body length ( $\mathrm{L} \mathrm{mm}$ ), weight ( $\mathrm{M}_{\mathrm{W}} \mathrm{g}$ ), scaled mass index (SMI g) and

568 estimation of the scaling exponent by the SMA regression of $\mathrm{M}_{\mathrm{W}}$ on $\mathrm{L}$ for each survey and

569 area with the $95 \%$ confidence intervals. SD: standard deviation; $\mathrm{n}$ : sample number. $\mathrm{L}_{0}$ used

570 were: $128.3 \mathrm{~mm}(\mathrm{n}=2151)$ for Gironde anchovy, $133.9 \mathrm{~mm}(\mathrm{n}=843)$ for South Brittany

571 anchovy, $167.3 \mathrm{~mm}(\mathrm{n}=1174)$ for Gironde sardine and $178.1 \mathrm{~mm}(\mathrm{n}=1156)$ for South

572 Brittany sardine.

\begin{tabular}{|c|c|c|c|c|c|c|c|c|}
\hline Survey & Species & Area & $\mathbf{n}$ & $\begin{array}{l}\mathrm{L} \pm \mathrm{SD} \\
(\mathrm{mm})\end{array}$ & $\begin{array}{c}\mathbf{M}_{\mathrm{w}} \pm \mathrm{SD} \\
(\mathrm{g})\end{array}$ & $\begin{array}{c}\mathrm{SMI} \pm \mathrm{SD} \\
(\mathrm{g})\end{array}$ & $\mathbf{b}_{\text {SMA }}$ & $\begin{array}{l}\mathbf{b}_{\text {SMA }} \\
\text { (CI 95\%) } \\
\end{array}$ \\
\hline \multirow{4}{*}{ P_May_09 } & Anchovy & \multirow{2}{*}{ Gironde } & 466 & $144.4 \pm 29.2$ & $24.0 \pm 15.0$ & $14.3 \pm 1.3$ & 3.23 & $3.19-3.27$ \\
\hline & Sardine & & 208 & $167 \pm 30.7$ & $38.6 \pm 20.4$ & $35.5 \pm 2.4$ & 2.96 & $2.91-3.01$ \\
\hline & Anchovy & South & 85 & $141.9 \pm 15.9$ & $22.4 \pm 8.6$ & $17.7 \pm 1.7$ & 3.31 & $3.13-3.50$ \\
\hline & Sardine & Brittany & 232 & $196.3 \pm 24.6$ & $65.6 \pm 22.3$ & $47.1 \pm 3.6$ & 2.99 & $2.92-3.07$ \\
\hline \multirow{4}{*}{ S_Aug_09 } & Anchovy & \multirow{2}{*}{ Gironde } & 226 & $131.2 \pm 15.8$ & $15.6 \pm 5.9$ & $13.9 \pm 1.0$ & 3.16 & $3.08-3.24$ \\
\hline & Sardine & & 120 & $183.0 \pm 22.4$ & $56.8 \pm 18.8$ & $42.1 \pm 4.1$ & 2.95 & $2.81-3.09$ \\
\hline & Anchovy & South & 40 & $176 \pm 10.8$ & $40.0 \pm 6.1$ & $20.1 \pm 1.5$ & 2.50 & $2.14-2.93$ \\
\hline & Sardine & Brittany & 139 & $177.8 \pm 9.0$ & $53.8 \pm 10.3$ & $53.6 \pm 3.9$ & 3.70 & $3.47-3.95$ \\
\hline \multirow{4}{*}{ S_Dec_09 } & Anchovy & \multirow{2}{*}{ Gironde } & 130 & $107.6 \pm 19.6$ & $7.4 \pm 4.0$ & $11.8 \pm 0.9$ & 3.28 & $3.21-3.34$ \\
\hline & Sardine & & 146 & $135.8 \pm 26.0$ & $21.6 \pm 16.4$ & $37.6 \pm 3.0$ & 3.31 & $3.24-3.38$ \\
\hline & Anchovy & South & 200 & $123.6 \pm 14.8$ & $10.8 \pm 4.2$ & $13.4 \pm 1.0$ & 3.38 & $3.30-3.47$ \\
\hline & Sardine & Brittany & 236 & $123.3 \pm 29.9$ & $16.7 \pm 13.5$ & $46.3 \pm 3.5$ & 3.36 & $3.32-3.40$ \\
\hline \multirow{4}{*}{ S_Apr_10 } & Anchovy & \multirow{2}{*}{ Gironde } & 250 & $131.0 \pm 17.7$ & $14.5 \pm 6.3$ & $12.7 \pm 0.9$ & 3.42 & $3.36-3.49$ \\
\hline & Sardine & & 240 & $179.5 \pm 33.1$ & $49.3 \pm 23.1$ & $35.0 \pm 3.2$ & 3.34 & $3.28-3.39$ \\
\hline & Anchovy & South & 40 & $120.4 \pm 13.2$ & $11.2 \pm 4.2$ & $15.0 \pm 0.9$ & 3.14 & $2.97-3.33$ \\
\hline & Sardine & Brittany & 40 & $227.9 \pm 12.7$ & $99.2 \pm 16.3$ & $46.9 \pm 2.4$ & 3.01 & $2.73-3.32$ \\
\hline \multirow{4}{*}{ P_May_10 } & Anchovy & \multirow{2}{*}{ Gironde } & 427 & $129.8 \pm 16.1$ & $15.1 \pm 6.6$ & $13.8 \pm 1.3$ & 3.21 & $3.14-3.28$ \\
\hline & Sardine & & 157 & $171.2 \pm 29$ & $41.9 \pm 19.9$ & $35.8 \pm 2.0$ & 3.11 & $3.06-3.16$ \\
\hline & Anchovy & Sou & 78 & $139.2 \pm 21.2$ & $19.8 \pm 9.6$ & $16.3 \pm 1.5$ & 3.14 & $3.01-3.28$ \\
\hline & Sardine & Brittany & 228 & $194.5 \pm 26.5$ & $61.8 \pm 23.6$ & $45.7 \pm 3.4$ & 2.91 & $2.84-2.98$ \\
\hline \multirow{4}{*}{ S_Jul_10 } & Anchovy & \multirow{2}{*}{ Gironde } & 124 & $109.4 \pm 21.2$ & $8.2 \pm 3.5$ & $12.1 \pm 1.4$ & 3.07 & $2.98-3.15$ \\
\hline & & & 0 & & & & - & . \\
\hline & Anchovy & South & 133 & $146 \pm 13.3$ & $22.1 \pm 6.7$ & $16.1 \pm 1.6$ & 3.38 & $3.20-3.57$ \\
\hline & Sardine & Brittany & 86 & $188.7 \pm 30.4$ & $59.8 \pm 28.1$ & $46.7 \pm 4.0$ & 3.00 & $2.89-3.11$ \\
\hline \multirow{4}{*}{ S_Sep_10 } & Anchovy & \multirow{2}{*}{ Gironde } & 139 & $115.2 \pm 11.0$ & $8.7 \pm 2.7$ & $11.9 \pm 1.0$ & 3.20 & $3.05-3.35$ \\
\hline & Sardine & & 118 & $142.5 \pm 26.8$ & $25.5 \pm 17.7$ & $37.8 \pm 3.2$ & 3.22 & $3.13-3.32$ \\
\hline & Anchovy & South & 76 & $141.1 \pm 16.4$ & $19.7 \pm 7.4$ & $15.7 \pm 1.7$ & 3.40 & $3.20-3.61$ \\
\hline & Sardine & Brittany & 85 & $182.3 \pm 16.6$ & $48.8 \pm 16.4$ & $42.5 \pm 11.0$ & 5.06 & $4.42-5.79$ \\
\hline \multirow{4}{*}{ P_May_11 } & Anchovy & \multirow{2}{*}{ Gironde } & 389 & $121.5 \pm 17.4$ & $11.8 \pm 5.1$ & $13.4 \pm 1.9$ & 3.55 & $3.45-3.65$ \\
\hline & Sardine & & 185 & $178.6 \pm 29.0$ & $47.2 \pm 21.7$ & $47.2 \pm 21.7$ & 3.17 & $3.10-3.24$ \\
\hline & Anchovy & South & 191 & $121.9 \pm 12.6$ & $12.8 \pm 4.3$ & $17.1 \pm 1.8$ & 3.50 & $3.36-3.65$ \\
\hline & Sardine & Brittany & 110 & $193.7 \pm 21.0$ & $59.8 \pm 18.0$ & $45.3 \pm 3.0$ & 2.94 & $2.83-3.05$ \\
\hline
\end{tabular}


575 Table 4. Engraulis encrasicolus samples analyzed for water content ( $\left.\% \mathrm{M}_{\mathrm{C}}\right)$ and energy 576 density $\left(\mathrm{E}_{\mathrm{D}}\right)$ by size class. Mean \pm S.D.

\begin{tabular}{|c|c|c|c|c|c|}
\hline Size class & $\begin{array}{l}\text { Codification } \\
\text { survey }\end{array}$ & Season & $\begin{array}{l}\text { Water content } \\
(\% \mathrm{Mc})\end{array}$ & $\begin{array}{l}\text { Energy density } E_{D} \\
\left(\mathrm{~kJ} \mathrm{~g}^{-1} \mathrm{Mw}\right)\end{array}$ & $\begin{array}{l}\text { Sample } \\
\text { number } n\end{array}$ \\
\hline Small & S_Aug_09 & Summer 2009 & $79.65 \pm 0.35$ & $3.40 \pm 0.14$ & 3 \\
\hline \multirow[t]{4}{*}{$\mathrm{L}_{\mathrm{T}}<100 \mathrm{~mm}$} & S_Dec_09 & Winter 2009 & $78.56 \pm 2.08$ & $3.85 \pm 1.22$ & 27 \\
\hline & S_Apr_10 & Spring 2010 & $79.49 \pm 2.04$ & $3.47 \pm 0.83$ & 7 \\
\hline & S_Jul_10 & Summer 2010 & $74.29 \pm 1.87$ & $5.60 \pm 0.77$ & 8 \\
\hline & S_Sep_10 & Autumn 2010 & $76.76 \pm 1.73$ & $4.59 \pm 0.71$ & 3 \\
\hline Medium & S_Aug_09 & Summer 2009 & $77.67 \pm 1.37$ & $4.21 \pm 0.56$ & 43 \\
\hline \multirow[t]{4}{*}{$100<\mathrm{L}_{\mathrm{T}}<140 \mathrm{~mm}$} & S_Dec_09 & Winter 2009 & $75.78 \pm 2.01$ & $4.99 \pm 0.82$ & 93 \\
\hline & S_Apr_10 & Spring 2010 & $77.51 \pm 1.64$ & $4.28 \pm 0.67$ & 80 \\
\hline & S_Jul_10 & Summer 2010 & $73.89 \pm 1.89$ & $5.77 \pm 0.78$ & 58 \\
\hline & S_Sep_10 & Autumn 2010 & $72.98 \pm 2.82$ & $6.14 \pm 1.16$ & 68 \\
\hline Large & S_Aug_09 & Summer 2009 & $76.30 \pm 1.61$ & $4.78 \pm 0.66$ & 53 \\
\hline \multirow[t]{4}{*}{$\mathrm{L}_{\mathrm{T}}>140 \mathrm{~mm}$} & S_Dec_09 & Winter 2009 & $75.11 \pm 1.61$ & $5.26 \pm 0.66$ & 25 \\
\hline & S_Apr_10 & Spring 2010 & $75.32 \pm 1.13$ & $5.18 \pm 0.46$ & 56 \\
\hline & S_Jul_10 & Summer 2010 & $72.97 \pm 1.70$ & $6.14 \pm 0.70$ & 48 \\
\hline & S_Sep_10 & Autumn 2010 & $70.64 \pm 5.08$ & $7.10 \pm 2.08$ & 24 \\
\hline
\end{tabular}

577 
579 Table 5. Sardina pilchardus samples analyzed for dry mass $\left(\% \mathrm{M}_{\mathrm{D}}\right)$ and water content $\left(\% \mathrm{M}_{\mathrm{C}}\right)$. $580 \quad$ Mean \pm S.D.

\begin{tabular}{|c|c|c|c|c|}
\hline Size class & $\begin{array}{c}\text { Codification } \\
\text { survey }\end{array}$ & Season & $\begin{array}{c}\text { Dry mass } \% \mathrm{M}_{\mathrm{D}} \\
\left.\text { (Water content } \% \mathrm{M}_{\mathrm{C}}\right)\end{array}$ & Sample number $\mathbf{n}$ \\
\hline Small & S_Aug_09 & Summer 2009 & - & - \\
\hline \multirow{4}{*}{$\mathrm{L}_{\mathrm{T}}<100 \mathrm{~mm}$} & S_Dec_09 & Winter 2009 & $21.17 \pm 1.29(78.83)$ & 18 \\
\hline & S_Apr_10 & Spring 2010 & - & - \\
\hline & S Jul 10 & Summer 2010 & - & - \\
\hline & S_Sep_10 & Autumn 2010 & - & - \\
\hline Medium & S_Aug_09 & Summer 2009 & - & \\
\hline \multirow[t]{4}{*}{$100<\mathrm{L}_{\mathrm{T}}<140 \mathrm{~mm}$} & S Dec 09 & Winter 2009 & $24.79 \pm 2.22(75.21)$ & 65 \\
\hline & S_Apr_10 & Spring 2010 & $23.58 \pm 1.62(76.42)$ & 19 \\
\hline & S_Jul_10 & Summer 2010 & $30.00 \pm 0.39(70.00)$ & 2 \\
\hline & S_Sep_10 & Autumn 2010 & $37.23 \pm 19.04(62.77)$ & 39 \\
\hline Large & S_Aug_09 & Summer 2009 & $30.06 \pm 1.66(69.94)$ & 29 \\
\hline \multirow[t]{4}{*}{$140<\mathrm{L}_{\mathrm{T}}<180 \mathrm{~mm}$} & S_Dec_09 & Winter 2009 & $27.66 \pm 2.36(72.34)$ & 61 \\
\hline & S_Apr_10 & Spring 2010 & $24.65 \pm 1.70(75.45)$ & 24 \\
\hline & $\mathrm{S}^{-} \mathrm{Jul}-10$ & Summer 2010 & $30.81 \pm 2.12(69.19)$ & 15 \\
\hline & S_Sep_10 & Autumn 2010 & $37.19 \pm 11.56(62.81)$ & 44 \\
\hline Very Large & S_Aug_09 & Summer 2009 & $30.02 \pm 2.30(69.98)$ & 35 \\
\hline \multirow[t]{4}{*}{$\mathrm{L}_{\mathrm{T}}>180 \mathrm{~mm}$} & S_Dec_09 & Winter 2009 & $28.79 \pm 1.98(71.21)$ & 15 \\
\hline & S_Apr_10 & Spring 2010 & $23.10 \pm 1.75(76.90)$ & 85 \\
\hline & S_Jul_10 & Summer 2010 & $30.60 \pm 2.18(69.40)$ & 30 \\
\hline & $\mathrm{S}$ Sep 10 & Autumn 2010 & $42.91 \pm 16.15(57.09)$ & 30 \\
\hline
\end{tabular}

